\title{
Rural Tourism: Community Empowerment in Sustainable Development
}

\author{
Ufi Saraswati ${ }^{1 *}$ \\ ${ }^{1}$ Department of History, Faculty of Social Sciences, Universitas Negeri Semarang, Indonesia \\ *Corresponding author.Email: ufiratri@mail.unnes.ac.id
}

\begin{abstract}
Along with the dynamics of world and global economic growth, today a new strategy or direction is needed for Indonesia's development policy. Development that combines growth and equality for the welfare of the entire nation takes effort strategy in accordance with the 1945 Constitution. The strategy is meant Empowerment Basic Strategy outlined in the three (3) directions discretion, include three (3) main points, namely, 1. advocation and empowerment, 2. Consolidation of autonomy and delegation of authority in the management of local development that develop community participation, and 3. Modernization by sharpening and strengthening the direction of change in socioeconomic and cultural structure rooted in local communities. One of the development strategy in order to strengthen local autonomy among them is the idea of the commission was asking the Ministry of Tourism (Kemenpar) RI, to develop alternative tourism destination for the development of tourist destinations in each province / state / city in efforts to comply with foreign tourists. Indonesia with 17.000 potential natural wealth of the 3.000 islands scattered tribes / ethnic nation is the wealth of foreign exchange at the same field for economic development, particularly in the tourism sector. Economic growth in rural communities has been classed as a people's economy, which is defined as an economy or economic development of a community group that is developing relatively slowly, in this case in rural communities. More popular economy and micro-operational nature, therefore the development of rural tourism can be a solution in an effort to accelerate the economic growth of the Indonesian people. Today, Indonesia with 74.910 villages are the potential that can be developed for tourism in every village. Every village in Indonesia is believed to have economic potential that can be developed and built in addition to agriculture or fisheries and others, namely the Tourism Village. With village tourism as an alternative, it is hoped that the village funds provided by the Government can encourage the village economy to grow rapidly and the village to progress according to the mandate of the UUD 1945 in the corridor of sustainable development.
\end{abstract}

Keywords: Rural Tourism, Community Empowerment, Sustainable Development.

\section{INTRODUCTION}

One of the objectives of development in Indonesia is the welfare of a just and prosperous society, both at the center and in the regions as stated in the UUD 1945. In its development, the development planned and carried out by the Government sometimes does not match the goals and objectives of development. As a result of the mismatch of development goals, many people have not been able to enjoy the results of development.

People who have not fully enjoyed development include those in the periphery, including the frontier, outermost and underdeveloped areas of the Republic of
Indonesia and rural communities. In these areas, some of them have untapped potential. The potentials include, among others, the potential for natural beauty, ancestral traditions and customs, as well as unique physical cultural relics (for example, residential houses, traditional clothing, and living tools) which are different and second to none elsewhere. This potential can be explored, used and utilized to a large extent for the prosperity of the local community.

The Indonesian government has recently declared sustainable development (Sustainable Development). Sustainable development has become a global agenda in every development process. The process of sustainable development is nothing but a development concept that is based on optimizing both natural 
resources (SDA) and human resources (HR) and, or harmonizing natural resources with humans in development.

Conceptually sustainable development is nothing but a progressive transformation of the Social, Economic and Political structures. Progressive Transformation is meant to be an effort to improve the welfare of society in fulfilling the interests of their life without sacrificing most of their resources, with the aim of being sustainable for the benefit of future generations. All stakeholders in various development sectors including the Government must apply the principles of sustainable development in every development policy and plan that will be implemented.[1]

The main targets for the achievement of sustainable tourism development include three (3) things, namely 1 . The quality of environmental resources, both the natural environment and the cultural environment, 2. the socio-economic quality of the local community, and 3. the quality of tourists in conducting and gaining experience from tourism activities. . On the basis of these three main goals, empowering local communities is an important paradigm for its achievement, because tourism is a community-based activity.[2]

The resources and uniqueness of the local community, both in the form of physical and nonphysical elements in the form of inherent values, norms, customs and traditions, are the main driving elements of the dynamic development of the culture and traditions of the community where this potential is located. On the other hand, the environment or ecological systems that live and grow side by side with local communities cannot be denied as part of tourism resources.

Tourism resources include the development of rural tourism. Rural Tourism by empowering the potential of natural and human resources can be a step to advance the economy in Indonesia. Currently, it is recorded that Indonesia has a total of 74,910 villages, with the potential to develop tourism in each village. There are at least 4 (four) priority programs for the development of rural tourism, namely: 1. Development of superior village products, 2. Villageowned enterprises, 3. development of reservoirs (water reserves), and 4. Development of village sports facilities.[3]

Building a tourism village according to the Ministry of Tourism does not only capitalize on beautiful scenery, but there are several criteria and important things as the main capital in developing Village Tourism, namely the potential of Nature, and the results of creative culture produced by rural communities.

\section{COMMUNITY EMPOWERMENT IN DEVELOPMENT \\ 2.1.Meaning of Community Empowerment}

Community empowerment is defined as a development process in which the community takes the initiative to initiate a social activity process to improve their own situation and condition. Community empowerment can only occur if the community itself participates.

In the context of development, the term empowerment is basically not a new term, but has often been used since the awareness that the human factor plays an important role in development. The main approach in the concept of empowerment is that the community is not made the object of various development projects but is placed as the subject of its own development efforts.

On the basis of this concept, community empowerment can be interpreted as follows, namely, directed efforts aimed at meeting needs through planning programs to overcome the problem. The planning program that is designed must include the target community. Directly involving the community has several objectives, among others, so that the assistance provided can run effectively in accordance with their needs, for that first an introduction to the ability or potential of the target community. On the one hand, a group approach should be used, considering that it is difficult for the poor to solve the problems they face if they are done individually, and on the other hand, if done individually, the handling of poverty alleviation is too broad. The group approach is seen as the most effective and more efficient when viewed from the use of human resources.

\subsection{Community Empowerment Strategy}

The purpose of community empowerment in development requires a strategy and direction. The strategies and directions referred to are, 1 . In favor of community empowerment efforts through predetermined studies, 2. Consolidating autonomy and delegation of authority in the management of regional development by developing community participation, and 3. Modernization through sharpening and strengthening the direction of structural change socioeconomic and cultural originating from the role of local communities.[4]

Strategies and directions are needed as an effective and efficient means of achieving poverty 
alleviation in sustainable development. Poverty alleviation can thus be resolved the root of the problem and it is hoped that it will not emerge again as a problem. The strategy and direction in sustainable development also means the concept of preservation, so that the existing potential can be enjoyed by future generations.

\subsection{Indicators of Success for Community Empowerment}

Community Empowerment in Development should be carried out with careful planning by involving the community in order to recognize the problem. Furthermore, on the basis of planning the community empowerment program it is necessary to conduct an evaluation, to measure the achievement of success indicators.

The success indicators used to measure the implementation of community empowerment programs include; a. Reducing the number of poor people, $b$. The development of income generation efforts carried out by the poor by utilizing the available resources, c. Increase public awareness of efforts to improve the welfare of poor families in their environment, $d$. Increasing group independence, which is indicated by the more productive business development of members and groups, stronger group capital, tidier group administration system, and wider group interaction with other groups in society, e. Increased community capacity and income distribution which is indicated by an increase in the income of poor families for the ability to meet basic needs and basic social needs [5].

The indicators of success that will be achieved are of course not immediately fulfilled in all indicators, but in stages the realization. Indicators of the success of community empowerment programs are evaluated per stage, tightly controlled for indicators that have been achieved and maximization of indicators that have not been achieved. Given the potential of each region and the heterogeneous real conditions of society, the percentage of each success indicator is certainly not the same. There are areas with abundant natural resource potential but not supported by human resources, on the other hand, areas with unique and high value cultural potentials are not always supported by their natural potential.

The role of the evaluator in assessing and reading the indicators of success on the target object and subject is the determining factor. The policy of the achievement of success indicators is the basis for improvement in further community empowerment programs.

\subsection{Community Empowerment Sustainable Development}

Community empowerment as one of the main concerns in sustainable development should be placed and oriented in the same direction and in line with the development approach paradigm. The top-downoriented development paradigm so far needs to be changed to a bottom-up approach, thus placing rural communities at the center of development or by Chambers in Anholt (2001).

According to [6] the bottom-up-oriented development paradigm must have the principle of initiative and encouragement of community interests. In this case, the community must be given the opportunity to be involved directly or through their representatives in the entire development planning and implementation process. The community should also be involved in ownership and control of infrastructure assets, so that the distribution of profits and benefits will be more equitable and felt directly by the community.

Sustainable development that creates empowered, independent and prosperous communities is very much needed in community empowerment. In this case the community is expected to be directly involved in sustainable development. The community does not only receive assistance in the form of a physical form, but also alleviates the problem itself. It is hoped that direct involvement can foster a development potential that is just and widely accepted by the community in the hope that it will not cause negative turmoil that is potentially detrimental.

Sustainable community development based on empowerment is expected to change the paradigm. Community support, which was originally passive and lazy, has become more enthusiastic and motivated to work. In order to realize the hope of a better community development, a community assistance method is needed that involves several parties with competences in the economic, social and cultural fields.[7]

\section{RURAL TOURISM}

The community becomes the main actor as well as the party that plays a role as both the subject and object of sustainable development in the tourism sector. Community involvement is expected to have hereditary experiences in the management of natural resources, culture and economic activities. Sustainable tourism development has a strong commitment regarding the interests of empowering the lives of local communities.

Empowerment of local communities then needs to be based on the following matters, 1. Advancing the 
level of community life while preserving local cultural identities and traditions, 2. Increasing income levels economically while distributing equitably to local residents, 3. Oriented to small-scale business development and medium with large absorption capacity and oriented to appropriate technology, 4. Developing a competitive and cooperative spirit, 5 . Making optimal use of tourism as a contributing agent for cultural traditions with minimal impact.[8]

The potential that the village has, including the natural environment, cultural products, customs and traditions is a "treasure" that can prosper people's lives. This potential is often overlooked and not explored as a potential for local community empowerment programs. Sustainable development in relation to the basic potential of a community should be in line with community empowerment in the region. Among the programs offered are Rural Tourism.

Several principles that are important to pay attention to in the development of a Tourism Village include, among others, product aspects, Human Resources (HR) Management and Institutions, Promotion and Marketing and Investment. Tourism Village development must be supported by qualified, competent Human Resources, understand and understand the principles and concepts of Tourism Village, work honestly, totality and have high loyalty to their obligations. Human Resources managing Village Tourism activities must have the ability to control various elements of the Village locality as the main attraction.[9]

Tourism Village development needs to be supported by management or management with a solid, flexible and simple and dynamic institution. Tourism Village management institutions should be independent, involve village leaders and local communities and be based on the principle of benefit not the principle of profit (profit oriented). Article 77 paragraph (1) of Law No. 6 of 2014 concerning Villages states that the management of villageowned wealth is based on the principles of public interest, functionality, legal certainty, openness, efficiency, effectiveness, accountability, and certainty of economic value. As for Article 77 paragraph (2) of the same law, it outlines the provision that the management of village property is carried out to improve the welfare and standard of living of the community and increase village income.

The involvement of local communities is the main element in the management of the Tourism Village. Local community involvement to take an active part in all processes which include Planning, Implementation and Supervision. This includes the involvement of local communities in the exploitation of economic activities that can be developed from Tourism Villages (Micro Small and Meddium Entrepreneurship). The development of the Tourism Village thus encourages the community to grow a sense of belonging (sense of belonging) to the development of tourism in their village. The village community will thus receive benefits and simultaneously act as managers.[10]

Community empowerment through the village tourism program in the next process is directed at the concept of conservation. The concept of preservation is expected to raise awareness of the importance of the values of life from the potential of a community to the next generation in accordance with the corridor of sustainable development. It is no less important to develop a more focused and selective promotional and marketing strategy with a combination of on-line (Digital, Electronic) and offline (Roadshow, FamTrip) promotions for Village Tourism.

The character of rural tourism activities as a form of alternative tourism today has a high bargaining position, considering that villages have long ago had potential that cannot be underestimated. One of them is its natural potential which can be used as a tourist attraction in locations that often provide views of local beauty that do not exist elsewhere. Tourists today tend to look for unique places with beautiful scenery to make rural areas a tourist destination. The potential of rural nature is the main attraction for those who want to feel peace, coolness and freshness, while at the same time keeping away from all the hustle and bustle of the city.

Village Tourism in addition to offering rural nature with its beauty and comfort, there is also local wisdom that is passed down from one generation to the next. It is not uncommon for local wisdom that the local community possesses, among others, the spirit of togetherness, harmony and mutual cooperation which are life values that must be maintained.

Another potential of a village, namely archaeological cultural heritage passed down from their ancestors, for example temples (temples), inscriptions, statues and so on. Especially for village areas that still have archaeological remains, this is a high-value potential, because the village area has existed since the Hindu Buddhist era in the archipelago. In one of the ancient Javanese village inscriptions it is called Wanua. Satu Wanua consists of several smaller settlements which are roughly the same as Dusun.[11]

Each tourist village promises its respective advantages based on geographic location, land construction, social typology, and the characteristics of the community. The success of a tourism village can reap benefits, if it is supported by the ability of the managers to specialize in its promotion, this is due to the "selling value" as a characteristic of each tourist village. 
The utilization of a village's potential in Village Tourism can trigger the rise of villagers as local people from poverty. It is hoped that the percentage of village poverty with community empowerment can be minimized through the Rural Pariwasata. The existence of village tourism will be able to boost the productivity of residents through the utilization of strategic locations which will directly or indirectly succeed the empowerment of local communities in the sustainable development section.

The development of tourist villages recently has helped the central government in reducing unemployment. The existence of several points in the region that are able to attract visitors certainly opens up a large area of work, so that the competence of the younger generation can be maximally empowered. Finally, the young generation can work without leaving their homeland. Rural economic life has not experienced a significant change in obtaining a bachelor's degree, and even if there are those who succeed in obtaining a bachelor's degree, they do not necessarily return to the village. They are more interested in working in modern institutions in the area or suburbs. Therefore, rural modernization is running quite slowly.[12]

The rise of tourists both from within and outside the country visiting inland areas should be taken seriously by the village government by optimizing the specialty of the local area as tourism potential. Village assets, among others, in the form of communal land, markets, forests, springs, public baths, etc. must really be used to establish the village as a favorite tourist destination. Apart from being used for operational costs, the income obtained from this local level business can also increase the village treasury. Thus, tourism village development can be carried out independently, because it does not only depend on financial transfers from the APBN and APBD which are called village funds and village fund allocations. The reduced dependence on supra village power makes the village more creative and innovative.

Every citizen with low income or even without income can take part in developing a private village, facilitated by the village apparatus. In this context, the policy of the village head and the neutrality of other civil servants is the main key to spreading employment opportunities. Job descriptions as well as profit sharing determined from Village Tourism should prioritize common interests. The commercialization of a number of locations should not be trapped in individualism. As a result, the management of a tourism village only involves people who have been in a "circle of power", such as relatives and colleagues of the village officials. They are the ones who have a special relationship with the local elites.
The development of a tourist village as an object and attraction will relate to tourists or visitors who live in a traditional village or close to traditional villages, or just for stopover visits, where the location of this tourist village is usually located in a remote area. Tourists or visitors not only witness traditional culture, but usually participate directly in local community activities.

The development planning approach that is usually carried out includes a community approach or community based development model. The local community in this case builds, owns and manages the tourism facilities and services directly from the developed Village Tourism, so that the community is expected to receive direct economic benefits and prevent urbanization. Emphasis on traditional life patterns is an important thing to consider, preparing for spontaneous interactions between the community and tourists or visitors to be able to provide visitors with understanding and knowledge about the local environment and culture in addition to giving local people a sense of pride in their culture.

It is necessary to consider the number of lodgings, traditional types of transportation, and others in the process of developing a village as a tourism destination. The construction of a simple traditional inn using local materials, traditional methods and forms is expected to give a distinct impression to visitors, including traditional cuisine.

Zoning arrangements and structuring the natural environment around the village need to be done in addition to providing facilities for tourists or visitors. Zoning for a tourist village needs to be considered the front stage and back stage or the front and rear areas. The front area is a place of experience, artificial or artificial, but still related to themes from local customs and culture. Here, tourists do not directly experience the original culture. This area is intended to attract tourists or give an initial impression to tourists or visitors. The tourist facilities and services that are grouped in the front area include accommodation, souvenir shops, food stalls and so on. The back area is the main attraction, namely the settlement of indigenous people with all their cultural activities. Here tourists or visitors are expected to get an authentic authentic cultural experience.[13]

\section{CONCLUSION}

The development of a tourist village can be a step to advance the rural economy in Indonesia. A tourism village is a form of integration between attractions, accommodation and supporting facilities that are presented in a structure of community life that is integrated with the prevailing procedures and traditions. The four priority programs include 1 . 
Development of superior village products, 2. Villageowned enterprises, 3. Development of reservoirs, and 4. Development of village sports facilities. Each village is believed to have economic potential other than agriculture or fisheries which can be developed and developed as a tourism destination. Village funds provided by the government are expected to encourage the village economy to grow rapidly and the village to progress along with sustainable development.

Indonesia currently has 74,910 villages that have the potential to be developed as objects and subjects of Village Tourism. Building rural tourism requires a separate market segment. The development of a tourism village must be planned carefully so that the impacts that arise can be controlled. Based on research and studies from UNDP / WTO and several Indonesian consultants, two development model approaches were achieved in formulating a framework / working concept from developing a village to a tourism village.

The first development model is an approach in which the village benefits without direct interaction with tourists. Approaches in this way include the use of on line promotions (Digital media, Electronics). The second development model is an approach by way of direct interaction with tourists, including attractions and direct introduction by tourists about village life, local arts and culture, traditional architecture, historical backgrounds, making postcards and so on.

The approach is a general solution in developing a village, especially in the framework of sustainable development. The concept of conservation can also be applied in conjunction with sustainable development for rural tourism development. The approach uses the concept of conservation when compared to the previous approach model, so in this concept special standards are used to control developments that apply conservation activities. Conservation Activities are a continuous effort to maintain the values of local wisdom as an importantpotential in the development of Village Tourism. Conservation activities in the development of village tourism are at the core of sustainable development.

Conservation efforts that can be made to maintain village tourism assets include conserving a number of houses that have high cultural and architectural value and changing the function of a residential house into a village museum, conserving the entire village and providing new land to accommodate the development of the villagers and at the same time developing land. it is a tourism area with tourist facilities. Conservation is a necessity in the Village Tourism Community Empowerment program. Conservation or preservation is intended so that the natural and cultural potential of a village can be sustainable for the next generation to enjoy, in addition to local communities who are empowered to alleviate poverty as the goal of
Community Empowerment in Sustainable Development.

\section{REFERENCES}

[1] Salim. Emil. 2010. Pembangunan Berkelanjutan Peran dan Kontribusi. Jakarta : PT. Gramedia Pustaka Utama

[2] Abdurrahman. 2003. Pembangunan Berkelanjutan Dalam Pengelolaan Sumber Daya Alam Indonesia. disampaikan pada Seminar Pembangunan Hukum Nasional VIII. Denpasar.

[3] Adisasmita, Rahardjo. 2006. Pembangunan Pedesaan dan Perkotaan. Yogyakarta: Graha Ilmu

[4] Harmet, Hari. 2001. Strategi Pemberdayaan Masyarakat. Bandung: Humaniora Utama Pers

[5] Suhendra. 2006. Peran Birokrasi Dalam Pemberdayaan Masyarakat. Bandung: Alfabeta

[6] Nasikun. 2000. Sistem Sosial Indonesia. Jakarta: Grafindo

[7] Suhendra. 2006. Peran Birokrasi Dalam Pemberdayaan Masyarakat. Bandung: Alfabeta

[8] Gunn, Clare A. 2002. Tourism Planning. New York City : Taylor and Francis

[9] Yoeti, Oka.1996. Pengantar Ilmu Pariwisata. Bandung : Penerbit Angkasa

[10] Chambers, Robert. 1998. Pengembangan Desa Mulai Dari Belakang. Jakarta: LP3ES

[11] Christie, Jan Wisseman.1982. "Patterns of trade in Western Indonesia : Ninth Throgh Thrteenth Centuries AD ( Vol I \& II)". Disertation. London: University of London

[12] Mulkhan Abdul Munir. 2009. Santri Sableng Sebuah Catatan Dari Bilik Pesantren. Yogyakarta: Leutika.

[13] Chambers, Robert. 1998. Pengembangan Desa Mulai Dari Belakang. Jakarta: LP3ES 